\title{
Physico-Chemical and Bacteriological Analysis of Drinking Water of Springs of Sherqilla, District Ghizer, Gilgit-Baltistan, Pakistan
}

\author{
Nadia Islam ${ }^{1}$, Khalil Ahmed ${ }^{1, *}$, Maisoor Ahmed Nafees ${ }^{1}$, Mujtaba Khalil ${ }^{2}$, \\ Ishtiaq Hussain ${ }^{3}$, Muhammad Ali ${ }^{1}$ and Raja Imran ${ }^{1}$
}

${ }^{1}$ Department of Biological Sciences, Karakoram International University, Gilgit-Baltistan ${ }^{2}$ The Aga Khan Medical University, Karachi

${ }^{3}$ Department of Biological Sciences, University of Baltistan Skardu

\begin{abstract}
A B S T R A C T
This study was conducted to determine the physico-chemical and bacteriological status of drinking water of Mishto uch (good spring) and Bar (big spring) springs of Sherqilla village, District Ghizer during winter and spring seasons. A total of twenty one samples were collected and analyzed by membrane filtration method. At Misto uch, the mean temperature was $9.7^{\circ} \mathrm{C}$ and $15.4^{\circ} \mathrm{C}$, turbidity was 0.44 NTU and $0.67 \mathrm{NTU}$, electric conductivity was $147.4 \mu \mathrm{S} / \mathrm{cm}$ and $226.7 \mu \mathrm{S} / \mathrm{cm}$, total dissolved solids was 99 $\mathrm{mg} / \mathrm{l}$ and $118 \mathrm{mg} / \mathrm{l}, \mathrm{pH}$ was 6.8 and 6.8 and total phosphorus was $48.3 \mu \mathrm{gP} / \mathrm{L}$ and $64.3 \mu \mathrm{gP} / \mathrm{L}$ in both the seasons. Whereas Bar spring the mean values in both the seasons were $10.8^{\circ} \mathrm{C}$ and $16.0^{\circ} \mathrm{C}$ for temperature, $0.21 \mathrm{NTU}$ and $0.36 \mathrm{NTU}$ for turbidity, $177 \mu \mathrm{S} / \mathrm{cm}$ and $268.8 \mu \mathrm{S} / \mathrm{cm}$ for electric conductivity, $104.8 \mathrm{mg} / 1$ and $115 \mathrm{mg} / \mathrm{l}$ for total dissolved solids, 6.9 and 6.9 and $58 \mu \mathrm{gP} / \mathrm{L}$ and $94 \mu \mathrm{gP} / \mathrm{L}$ for total phosphorus. Escherichia coli, Enterrococci and total bacterial count at the eye of spring of Mishto uch was zero during winter while other sampling sites showed an average of $17.4 \mathrm{CFU} / 100 \mathrm{ml}$ and $55.4 \mathrm{CFU} / 100 \mathrm{ml}$ E.coli, 15.4 CFU/100ml and 20.7 CFU/100ml Enterrococci, and 26.4CFU/100ml and $127.7 \mathrm{CFU} / 100 \mathrm{ml} \mathrm{TBC}$ in both the seasons at Mishto uch. All the sampling sites of Bar spring did not show E.coli and Enterrococci in both seasons, TBC was within range of $7.0 \mathrm{CFU} / 100 \mathrm{ml}$ and $64.3 \mathrm{CFU} / 100 \mathrm{ml}$ in both the seasons. The results will help to improve the quality of drinking water for the community of Sherqilla.
\end{abstract}

Article Information
Received 17 July 2016
Revised 25 May 2017
Accepted 31 January 2018
Available online 26 February 2021
Authors' Contribution
NI conducted the research and wrote
the mansucript. KA superved the
project. MAN and RI assessed samples
in lab. MK collected samples. IA
analysed the data. MA proofread and
edited the article.
Key words
Bacteriological quality of water
of springs, Chemical analysis of
water of Gilgit-Baltistan, Physico-
chemical analysis of drinking water,
Microbiological analysis of water,
Physical-chemical analysis of springs
water.

\section{INTRODUCTION}

$\mathrm{W}$ ater is one of the greatest gifts given by nature to fulfill all the essential requirements of living organisms including growth, maintenance of body and performance of all life supporting activities (Simpi et al., 2011). Water is an important resource for bio-diversity, food security, environmental resources, agriculture and for sustaining all forms of life (Munair, 2003). The availability of safe drinking water plays an important role in human physiology and existence of life on the planet Earth (FAO, 1997).

The main sources of water are seas, oceans, lakes, ponds, wells, rivers, glaciers, icebergs and springs (Dan'azumi and Bichi, 2010; Rajkumar et al., 2003; Tamot and Bhatnagar, 1998). Seventy-one percent of Earth's surface is covered by ocean and seas, which provide $96.5 \%$ of planet Earth's water. The second and third largest reservoirs of water are ground water and glaciers, each contributing $1.7 \%$ to total global need. Fresh water makes

\footnotetext{
* Corresponding author: dr.khalil@kiu.edu.pk 0030-9923/2021/0002-0713 \$9.00/0

Copyright 2021 Zoological Society of Pakistan
}

up a minute fraction, which is $2.5 \%$ of Earth's water, and $99 \%$ of all fresh water supplies are found in glaciers and groundwater with nearly a quarter of the world's population relying on these water two sources (Jackson et al., 2001).

According to United Nations Development Program, nearly one-sixth of the world's population has access to unsafe sources of drinking water (UNDP, 2006). An estimated 4 billion people die per year, out of which $30 \%$ are associated with unsafe drinking water (Montgomery and Elimelech, 2007) and in developing countries, $80 \%$ of deaths occurred due to water related diseases, of which $15 \%$ are children under the age of five years (Thompson and Khan, 2003; WHO, 2003, 2004; Holgate, 2000).

The presence of pathogenic organisms in drinking water make it unsafe and causes disease. People in developing countries suffer from a number of diseases due to insufficient water supply, bad sanitation and hygiene conditions (World Bank, 2002b). The shortage of safe water and contamination of fresh water has led one-fifth of the urban inhabitants and three-quarters of the rural resident population to be without access to clean water sources (Lloyd and Helmer, 1992).

To reduce the number of diseases and ensure safe distribution of drinking water to the community, it must be 
free of pathogens and physico-chemical contaminations. The World Health Organization (1993) has set standard guidelines or limits for drinking water. If the water parameters are within the limits, water is considered potable.

Pakistan ranked $80^{\text {th }}$ in the world in the accessibility of safe drinking water to its people (Azizullah et al., 2011). Over $65 \%$ of the total population is believed to have access to safe drinking water (GoP, 2005; World Bank, 2002a; Khan and Javed, 2007; Khan, 2000) and 44\% lack such access. Up to $90 \%$ of the rural population of Pakistan is without access to safe, drinkable water (The United Nations System in Pakistan, 2003).

According to the Pakistan National Conservation Strategy 1992 and country report of Pakistan in 2000, bad water quality causes $30 \%$ of all deaths and $40 \%$ of all diseases in the country, and the leading cause of death in newborns and children is diarrhea, a water related disease caused by polluted water (Kahlown et al, 2006).

Gilgit-Baltistan, Pakistan, is rich in natural resources, with an area of about $72,971 \mathrm{~km}^{2}$ and at an elevation of 3000 meters (GBPI, 2009-2011). It is covered with lofty mountains and these mountains separate different areas from each other. It is home to a population of 1.8 million (PCO, 2008). Gilgit-Baltistan has three divisions: Gilgit, Baltistan and Diamer and includes the districts of Gilgit, Diamer, Hunza, Nagar, Ghizer, Astore, Baltistan and Ghanche. Climatic conditions range from monsoons to the arid and semi-arid desert. The temperature in summer gets as high as $40^{\circ} \mathrm{C}$ and falls to $-10^{\circ} \mathrm{C}$ in winter (Ahmed and Joyia, 2003).

In Gilgit-Baltistan, precipitation (rainfall), stream flow and springs are the main sources of water. Spring water is available in many areas of Gilgit-Baltistan, as glacier and snow deposits are the main sources of water. Springs make a specific fraction of the hydrosphere. Springs are a natural source of water for human usage that originates from underground water deposits and is protected from environmental contaminations. One of the benefits of spring water is that at the point of origin, water is clean and clear.

The present study was designed to provide more information about the physico-chemical and microbial quality of spring water in the Sherqilla valley of Ghizer district. The study was formatted to determine the physico-chemical and microbial parameters of two springs of Sherqilla valley, District Ghizer. The main goal of this study was to develop baseline data to educate the community and to identify major problems associated with water quality in the study area and to develop a future plan for management and treatment of water to ensure the safe distribution of drinking water to local inhabitants.

\section{MATERIALS AND METHODS}

\section{Study area}

This study was conducted in the Sherqilla valley, one of the most populated villages in tehsil Punial of the district Ghizer, $38 \mathrm{~km}$ west from the centre of Gilgit city. This village is rich with springs and the current study was conducted to analyze the physico-chemical and bacteriological properties of the drinking water of Mishto uch spring, which is located at an elevation of $1993 \mathrm{~m}$ and supplies water to Loi Das (Amin Abad), and Bar uch, at an elevation of $1843 \mathrm{~m}$ and which supplies water to the Karim Abad (Moss) and Majini Mahla (Ali Abad).

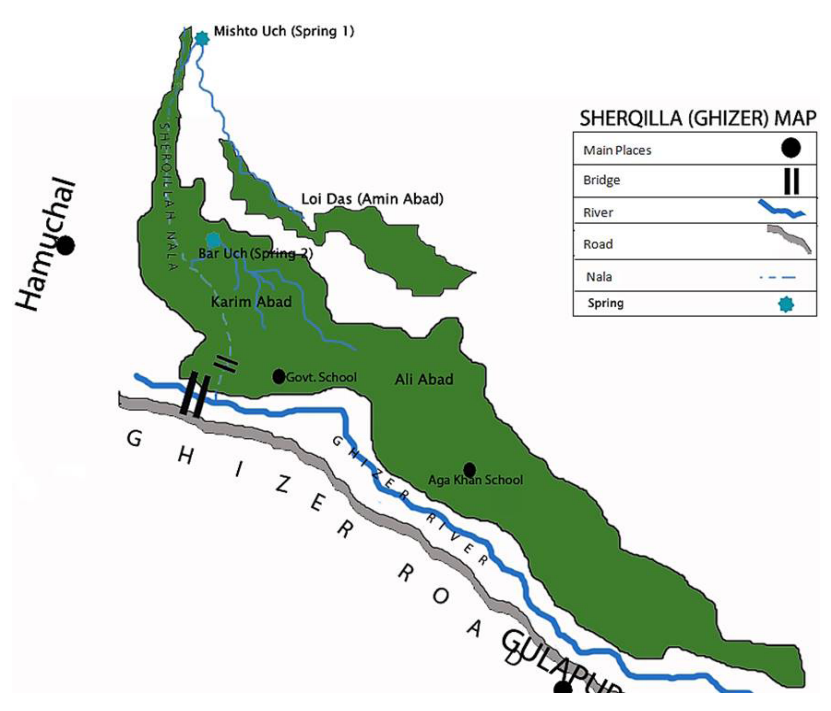

Fig. 1. Spring sites of Mishto uch, Bar and their supply system to various areas.

\section{Sampling procedure}

Twenty-one water samples were collected from the two springs from November 2013 to May 2014 during winter and spring. Twelve samples were obtained from the eye of the spring in Bar, three samples each from the source, inlet and outlet of the water reservoir and from distribution (tap water). Nine samples were collected from Mishto uch spring, including three samples from the source, three samples from the junction where spring water combines with glacier water, and three each from distribution (house). Elevation and temperature were measured on the spot sample collection using GPS and a mercury thermometer, respectively. Samples for physicochemical analysis were collected in polyethylene bottles, which were thoroughly rinsed thrice with the water before sampling. Samples for microbial analysis were collected directly from the springs in sterilized bottles from a depth of 20 to $30 \mathrm{~cm}$ below the water surface. This was done to 
avoid contamination deposited by air on the water surface, to avoid touching the bottom, and to prevent contaminating the samples by touching hands. While sampling from the distribution system (tap), the tap was cleaned from outside and opened fully to let water run to waste for at least 3 minutes. Bottles were filled completely and their caps were tightened. Samples were kept in the dark and refrigerated at about $2-8^{\circ} \mathrm{C}$, pending laboratory analysis, to avoid any chemical reaction. Samples were taken to laboratory and cultured within a few hours of their collection.

\section{Physico-chemical parameters}

Collected water samples were analyzed for the following physical, chemical and biological parameters: conductivity $(\mu \mathrm{S} / \mathrm{cm}), \mathrm{pH}$, turbidity (NTU), total dissolved solids $(\mathrm{mg} / \mathrm{l})$, total phosphorous $(\mathrm{mg} / \mathrm{l})$, reactive orthophosphate $(\mathrm{mg} / \mathrm{l})$, total bacterial count $(\mathrm{CFU} / 100 \mathrm{ml})$ and identification of Escherichia coli and Enterrococci.

\section{Bacteriological analysis}

Water samples collected for bacteriological analysis were cultured on Chromogenic X-Glu agar (Biolife, Italy), Slanetz and Bartley agar (Biolife, Italy), Bile Esculin Azide agar (BEA (Biokar diagnostics)) and Yeast Extract agar (BIOM lab, Malaysia). Standard Membrane Filtration technique was used for the enumeration of Escherichia coli (incubated at $40^{\circ} \mathrm{C}$ for $24 \mathrm{~h}$ ) and Enterrococci (incubated at $36^{\circ} \mathrm{C}$ for $44 \mathrm{~h}$ ) while Pour Plate technique was used for total bacterial count (incubated for at $22^{\circ} \mathrm{C} 72 \mathrm{~h}$ ).

\section{Physical analysis}

Temperature was measured at the point of sample collection with the help of a mercury glass thermometer. Turbidity was determined by using Nephelometric tube. Electric conductivity and total dissolved solids were measured by a digital conductivity meter (AD3000, ADWA).

\section{Chemical analysis}

UV Spectrophotometer (UV 23000II, model) was used to determine the concentration of total phosphorus and reactive orthophosphate by the following methods:

\section{Reactive orthophosphate}

Glassware (50ml Duran bottle blue cap GL32) was rinsed thoroughly with de-ionized and ultrapure water. Three blank samples were prepared along with test samples using $25 \mathrm{ml}$ of ultra-pure water in the place of test samples. $25 \mathrm{ml}$ of sample was pipetted into a $50 \mathrm{ml}$ polypropylene Erlenmeyer flask and $0.75 \mathrm{ml}$ of reagent mix was added, mixed and let to stand for 2-3 min before $0.75 \mathrm{ml}$ of reducing solution II was added. The mixture was allowed to sit for $15 \mathrm{~min}$ for colour to develop. Spectrophotometric determination was performed and a spectrophotometer was zeroed by using de-ionized water without reagents. Then it was calibrated with each blanked solution and the mean absorbance values of three blank samples were calculated. After calibration, the concentration of phosphorus in the water samples collected from sampling points was calculated, subtracting the blank mean absorbance from each sample's absorbance to calculate the total phosphorus concentration (Malcolm and Wong, 1990).

\section{Total phosphorus}

Glassware was rinsed thoroughly with de-ionized water. $25 \mathrm{ml}$ of water sample was pipetted into $50 \mathrm{ml}$ Duran bottles and $3.5 \mathrm{ml}$ of oxidizing solution (Reagent I) was added. Next, the bottles were placed in an autoclave at $120^{\circ} \mathrm{C}$ for 30 minutes. After autoclaving, the bottles were allowed to cool at room temperature. $0.75 \mathrm{~mL}$ of reagent mix II was added to autoclaved samples, let to sit for 2-3 min before $0.75 \mathrm{~mL}$ of reducing solution III was put in samples and colour developed after $15 \mathrm{~min}$. Again, a spectrophotometer was calibrated and readings of three blank solutions were noted before calculating the mean absorbance of other samples concentration of each water sample (Pote and Danial, 2001; Rowland and Haygrath, 1997).

$p H$

A digital pH meter (AD 1020, ADWA) was used to measure $\mathrm{pH}$ of water samples. Before use, the $\mathrm{pH}$ meter was calibrated with relevant buffer solutions.

\section{RESULTS}

\section{Physical analysis of drinking water \\ Mishto uch}

Table I shows the results of physical parameters of drinking water of Mishto uch spring at its various sampling points. Temperature recorded at the eye of the spring was $9.7^{\circ} \mathrm{C}$ in winter and $15^{\circ} \mathrm{C}$ in spring. At the junction where Mishto uch water combines with glacier water, the temperature showed $9.5^{\circ} \mathrm{C}$ in winter and $15^{\circ} \mathrm{C}$ in spring while distribution system samples taken from a house storage container were $10^{\circ} \mathrm{C}$ and $16^{\circ} \mathrm{C}$ in winter and spring, respectively.

Substantial variation in turbidity was found between the seasons at the spring source of Mishto uch, at a level of $0.26 \mathrm{NTU}$ in winter and $0.91 \mathrm{NTU}$ in spring. Slight variation, $0.85 \mathrm{NTU}$ and $0.87 \mathrm{NTU}$ in winter and spring, was found at the junction of the spring with glacier water. Similarly, 0.19 NTU in winter and 0.22 NTU in spring was recorded in the house storage container. 
Table I.- Physical parameters analyzed for the drinking waters of Mihsto uch and Bar sprinig.

\begin{tabular}{|c|c|c|c|c|c|c|c|c|c|}
\hline \multirow[t]{2}{*}{ Location } & \multirow[t]{2}{*}{ Sampling points } & \multicolumn{4}{|c|}{ Winter } & \multicolumn{4}{|c|}{ Spring } \\
\hline & & $\begin{array}{c}\text { Temp } \\
\left({ }^{\circ} \mathrm{C}\right)\end{array}$ & $\begin{array}{c}\text { Turbidity } \\
\text { (NTU) }\end{array}$ & $\begin{array}{c}\text { EC } \\
(\mu \mathrm{S} / \mathrm{cm})\end{array}$ & $\begin{array}{c}\text { TDS } \\
\text { (mg/l) }\end{array}$ & $\begin{array}{c}\text { Temp } \\
\left({ }^{\circ} \mathrm{C}\right)\end{array}$ & $\begin{array}{c}\text { Turbidity } \\
\text { (NTU) }\end{array}$ & $\begin{array}{c}\mathbf{E C} \\
(\mu \mathrm{S} / \mathrm{cm})\end{array}$ & $\begin{array}{c}\text { TDS } \\
\text { (mg/l) }\end{array}$ \\
\hline Mishto uch & Spring eye & 9.5 & 0.26 & 151 & 97 & 15 & 0.91 & 227 & 116 \\
\hline Mishto uch & Junction with glacier water & 9.5 & 0.85 & 148 & 99 & 15 & 0.87 & 223 & 118 \\
\hline Loi Das & Distribution system (House) & 10 & 0.19 & 143 & 101 & 16 & 0.22 & 230 & 120 \\
\hline Mean & & 9.7 & 0.44 & 147.4 & 99.0 & 15.4 & 0.67 & 226.7 & 118.0 \\
\hline Bar & Spring eye & 10 & 0.18 & 177 & 31 & 16 & 0.27 & 278 & 34 \\
\hline Bar & Inlet of reservoir & 11 & 0.32 & 162 & 136 & 16 & 0.43 & 242 & 141 \\
\hline Bar & Outlet of reservoir & 11 & 0.14 & 187 & 117 & 16 & 0.31 & 268 & 145 \\
\hline Karim Abad & Distribution system (Tape) & 11 & 0.21 & 182 & 135 & 16 & 0.42 & 287 & 140 \\
\hline Mean & & 10.8 & 0.21 & 177 & 104.8 & 16 & 0.36 & 268.8 & 115 \\
\hline
\end{tabular}

NTU, nephelometric turbidity unit; $\mu \mathrm{S}$, micro semen; mg/l, milligram per liter; EC, electrical conductivity; ${ }^{1}$ Temp, temperature, TDS, total dissolved solid.

Fluctuation was found in the conductivity values in the eye of the spring and at its various distribution systems. Levels of $151 \mu \mathrm{S}$ in winter and $227 \mu \mathrm{S}$ in spring were detected at the eye of the spring while at the junction, it was $148 \mu \mathrm{S}$ in winter and rose to $223 \mu \mathrm{S}$ in the spring. In the distribution system, $143 \mu \mathrm{S}$ and $230 \mu \mathrm{S}$ was recorded in both seasons.

TDS in the spring source had a mean value of $97 \mathrm{mg} / \mathrm{l}$ in winter and $116 \mathrm{mg} / \mathrm{l}$ in spring, while in junction it was $99 \mathrm{mg} / \mathrm{l}$ in winter and rose to $118 \mathrm{mg} / \mathrm{l}$ in spring. Similarly, the average of $101 \mathrm{mg} / 1$ and $120 \mathrm{mg} / \mathrm{l}$ was found at its distribution system during both the seasons.

\section{Bar spring}

Table I also shows the physical parameters of drinking water of Bar spring at the eye of the spring and at various points in its distribution system. At source, the temperature was $10^{\circ} \mathrm{C}$ in winter and $16^{\circ} \mathrm{C}$ in spring while in distribution system, including the inlet, outlet of the water reservoir and in the tap it was $11^{\circ} \mathrm{C}$ in winter and $16^{\circ} \mathrm{C}$ in spring. There was no change in temperature at various sampling points.

There was variation in turbidity at various points of sampling. At the source it was $0.18 \mathrm{NTU}$ in winter and 0.27 NTU in spring. At the inlet of the water reservoir, it was $0.32 \mathrm{NTU}$ in winter and $0.43 \mathrm{NTU}$ in spring, $0.14 \mathrm{NTU}$ in winter and $0.31 \mathrm{NTU}$ in spring at the outlet and $0.21 \mathrm{NTU}$ and $0.42 \mathrm{NTU}$ in winter and spring, respectively, in the distribution system.

Similarly, the conductivity showed much variation in both the seasons. In winter, it was $177 \mu \mathrm{S} / \mathrm{cm}$ and rose up to $278 \mu \mathrm{S} / \mathrm{cm}$ in spring. In the inlet of the water reservoir, it was $162 \mu \mathrm{S} / \mathrm{cm}$ in winter and rose up to 242 $\mu \mathrm{S} / \mathrm{cm}$ in spring. Similarly in the outlet of the reservoir it was $187 \mu \mathrm{S} / \mathrm{cm}$ in winter and $268 \mu \mathrm{S} / \mathrm{cm}$ in spring. In the distribution system, it was $182 \mu \mathrm{S} / \mathrm{cm}$ in winter and $287 \mu \mathrm{S} / \mathrm{cm}$ in spring.

The TDS has fluctuation in both the seasons at various sampling points. At the eye of the spring, it was $31 \mathrm{mg} / \mathrm{l}$ in winter rose up to $34 \mathrm{mg} / \mathrm{l}$ in spring. In the inlet of the water reservoir, it was $136 \mathrm{mg} / \mathrm{l}$ in winter and $141 \mathrm{mg} / \mathrm{l}$ in spring and in outlet it was $117 \mathrm{mg} / \mathrm{l}$ in winter and $145 \mathrm{mg} / \mathrm{l}$ in spring. While at distribution, it was $135 \mathrm{mg} / \mathrm{l}$ in winter and $140 \mathrm{mg} / 1$ in spring.

\section{Chemical analysis of drinking water Mishto uch}

Table II represents the findings of chemical analysis of drinking water from Mishto uch of Sherqilla valley. The $\mathrm{pH}$ at the eye of the spring of Mishto uch was 6.8 in winter and in spring and it remained the same at the junction of spring water with glacier water and in the distribution system during both seasons.

There was large fluctuation in the values of reactive orthophosphate at various sampling points. At the eye of the spring it was $28 \mu \mathrm{g} \mathrm{P} / 1$ in winter and $63 \mu \mathrm{g} \mathrm{P} / 1$ in spring. At the junction, $31 \mu \mathrm{gP} / 1$ and $43 \mu \mathrm{gP} / 1$ were noted in both the seasons and in distribution system, it was $19 \mu \mathrm{gP} / 1$ and $43 \mu \mathrm{gP} / 1$ in the winter and spring seasons.

The total phosphorus in the collected samples also showed variation. In the eye of the spring it was $46 \mu \mathrm{gP} / 1$ in winter and $78 \mu \mathrm{gP} / 1$ in spring. At junction point $48 \mu \mathrm{gP} / 1$ and $59 \mu \mathrm{gP} / 1$ and in distribution $51 \mu \mathrm{gP} / 1$ and $56 \mu \mathrm{gP} / 1$ were observed in both the seasons.

Bar spring

Table II shows the chemical parameters of drinking water from Bar spring. It can be clearly observed that the 
$\mathrm{pH}$ from different sites of the same location gave similar results. The detected $\mathrm{pH}$ value at the spring source of Bar was 6.5 in both the winter and spring seasons. However, a slight variation was seen at the inlet of the water reservoir, 7 in winter and 7.1 in spring. Similarly, at the outlet of water reservoir, 7, and in the distribution, 7.2, were observed in both the winter and spring seasons.

Typical values for reactive orthophosphate of the water samples collected from the spring eye of Bar spring was $41 \mu \mathrm{gP} / 1$ in winter and became $44 \mu \mathrm{gP} / 1$ in spring. In the inlet of the water reservoir, it measured $26 \mu \mathrm{gP} / 1$ in winter and $48 \mu \mathrm{gP} / 1$ in spring. In the outlet, it measured $22 \mu \mathrm{gP} / 1$ in winter and $41 \mu \mathrm{gP} / 1$ in spring, while in distribution system it was $21 \mu \mathrm{gP} / 1$ in winter and $41 \mu \mathrm{gP} / 1$ in spring.

Water samples analyzed for total phosphorus showed great variations. Samples taken from the spring source showed $57 \mu \mathrm{gP} / 1$ of total phosphorus in winter and rose up to $134 \mu \mathrm{gP} / 1$ in spring. $89 \mu \mathrm{gP} / 1$ in winter and $101 \mu \mathrm{gP} / 1$ in spring were found in the inlet of water reservoir. Similarly, $39 \mu \mathrm{gP} / 1$ and $50 \mu \mathrm{gP} / 1$ at the outlet and $47 \mu \mathrm{gP} / 1$ and $91 \mu \mathrm{gP} / 1$ in the distribution system were observed in winter and spring.

\section{Bacterial analysis of drinking water}

Mishto uch

Table III represents the bacterial analysis of drinking water quality of Mishto uch and its various distribution systems. High numbers of $E$. coli were found at various points of sampling. No E. coli and Enterrococci were detected in winter at the eye of the spring while 3 CFU/100ml of E. coli and $1 \mathrm{CFU} / 100 \mathrm{ml}$ of Enterrococci were present during the spring season. At the junction with the glacier water, the $E$. coli count were $33 \mathrm{CFU} / 100 \mathrm{ml}$ in winter and $79 \mathrm{CFU} / 100 \mathrm{ml}$ in spring. At the distribution system (house storage) $19 \mathrm{CFU} / 100 \mathrm{ml}$ and $84 \mathrm{CFU} / 100 \mathrm{ml}$ of $E$. coli were present in winter and spring, respectively. Numbers of Enterrococci found at the junction were 20 $\mathrm{CFU} / 100 \mathrm{ml}$ in winter and $31 \mathrm{CFU} / 100 \mathrm{ml}$ in spring. While in distribution system 26 and $30 \mathrm{CFU} / 100 \mathrm{ml}$ Enterococci in the winter and spring seasons.

Table II.- Chemical parameters analyzed for the drinking waters of Mishto uch and Bar sprinig.

\begin{tabular}{|c|c|c|c|c|c|c|c|}
\hline \multirow[t]{2}{*}{ Location } & \multirow[t]{2}{*}{ Sampling points } & \multicolumn{3}{|c|}{ Winter } & \multicolumn{3}{|c|}{ Spring } \\
\hline & & pH & $\begin{array}{c}\text { Reactive } \mathrm{PO}_{4} \\
(\mu \mathrm{g} \mathrm{P} / \mathrm{L})\end{array}$ & $\begin{array}{c}\text { Total phosphorus } \\
(\mu \mathrm{g} \text { P/L) }\end{array}$ & pH & $\begin{array}{c}\text { Reactive } \mathrm{PO}_{4} \\
(\mu \mathrm{g} \mathrm{P} / \mathrm{L})\end{array}$ & $\begin{array}{c}\text { Total phosphorus } \\
(\mu \mathrm{g} \mathrm{P} / \mathrm{L})\end{array}$ \\
\hline Mishto uch & Spring eye & 6.8 & 28 & 46 & 6.8 & 63 & 78 \\
\hline Mishto uch & Junction with glacier water & 6.8 & 31 & 48 & 6.8 & 43 & 59 \\
\hline Loi Das & Distribution system (House) & 6.8 & 19 & 51 & 6.8 & 43 & 56 \\
\hline Mean & & 6.8 & 26 & 48.3 & 6.8 & 49.6 & 64.3 \\
\hline Bar & Spring eye & 6.5 & 41 & 57 & 6.5 & 44 & 134 \\
\hline Bar & Inlet of reservoir & 7.0 & 26 & 89 & 7.1 & 48 & 101 \\
\hline Bar & Outlet of reservoir & 7.0 & 22 & 39 & 7.0 & 41 & 50 \\
\hline Karim Abad & Distribution system (Tape) & 7.2 & 21 & 47 & 7.2 & 41 & 91 \\
\hline Mean & Mean & 6.9 & 27.5 & 58 & 6.9 & 43.4 & 94 \\
\hline
\end{tabular}

Table III.- Bacteriological parameters (CFU/100ml) analyzed for the drinking waters of Mishto uch and Bar spring Sherqilla, District Ghizer.

\begin{tabular}{|c|c|c|c|c|c|c|c|}
\hline \multirow[t]{2}{*}{ Location } & \multirow[t]{2}{*}{ Sampling points } & \multicolumn{3}{|c|}{ Winter } & \multicolumn{3}{|c|}{ Spring } \\
\hline & & E. coli & Enterococci & $\begin{array}{c}\text { Total bacterial } \\
\text { count }\end{array}$ & E. coli & Enterococci & $\begin{array}{c}\text { Total bacterial } \\
\text { count }\end{array}$ \\
\hline Mishto uch & Spring eye & 0 & 0 & 23 & 3 & 1 & 66 \\
\hline Mishto uch & Junction with glacier water & 33 & 20 & 14 & 79 & 31 & 87 \\
\hline Loi Das & Distribution system (House) & 19 & 26 & 42 & 84 & 30 & 230 \\
\hline Mean & & 17.4 & 15.4 & 26.4 & 55.4 & 20.7 & 127.7 \\
\hline Bar & Spring eye & 0 & 0 & 0 & 0 & 0 & 19 \\
\hline Bar & Inlet of reservoir & 0 & 0 & 0 & 0 & 0 & 104 \\
\hline Bar & Outlet of reservoir & 0 & 0 & 6 & 0 & 0 & 14 \\
\hline Karim Abad & Distribution system (Tape) & 0 & 0 & 22 & 0 & 0 & 120 \\
\hline Mean & & 0 & 0 & 7.0 & 0 & 0 & 64.3 \\
\hline
\end{tabular}


Total bacteria count (TBC) showed great fluctuations in both seasons at the examined sites of Mishto uch spring. $\mathrm{TBC}$ at the spring eye was $23 \mathrm{CFU} / 100 \mathrm{ml}$ in winter and $66 \mathrm{CFU} / 100 \mathrm{ml}$ in spring. The junction point showed 14 $\mathrm{CFU} / 100 \mathrm{ml}$ and $87 \mathrm{CFU} / 100 \mathrm{ml}$ of TBC in winter and spring, respectively. However, the distribution system gave $42 \mathrm{CFU} / 100 \mathrm{ml}$ and $230 \mathrm{CFU} / 100 \mathrm{ml}$ of total bacteria in both seasons.

\section{Bar spring}

Table III also shows the bacterial analysis of drinking water of Bar spring Sherqilla. There were no E. coli and Enterrococci at different water sampling sites of Bar spring in both winter and spring. Total bacteria count (TBC) showed great variation among different sampling points. No bacteria were counted at the spring eye in winter while $19 \mathrm{CFU} / 100 \mathrm{ml}$ of TBC was found in spring. Again, the inlet of water reservoir of Bar spring was nil in winter and a huge number of TBC were noted in spring i.e. $104 \mathrm{CFU} / 100 \mathrm{ml}$. TBC detected at the outlet of reservoir were $6 \mathrm{CFU} / 100 \mathrm{ml}$ in winter and $14 \mathrm{CFU} / 100 \mathrm{ml}$ in spring. Similarly, $22 \mathrm{CFU} / 100 \mathrm{ml}$ were present in the distribution system in winter, which increased dramatically to 120 $\mathrm{CFU} / 100 \mathrm{ml}$ in the spring.

Table IV.- Permissible limits set by WHO Standards (1993) for drinking water quality.

\begin{tabular}{llc}
\hline S. No. & Parameters & $\begin{array}{c}\text { Standard guidelines } \\
\text { of WHO }\end{array}$ \\
\hline 1 & Temperature & $<25^{\circ} \mathrm{C}$ \\
2 & Turbidity & $<5 \mathrm{NTU}$ \\
3 & Conductivity & $1,000 \mu \mathrm{S} / \mathrm{cm}$ \\
4 & TDS & $<600 \mathrm{mg} / 1$ \\
5 & pH & $6.5-8.2$ \\
6 & Reactive orthrophosphate & $10-50 \mathrm{mg} / \mathrm{L}$ \\
7 & Total phosphorus & $5 \mathrm{mg} / 1$ \\
8 & E. coli & $0 / 100 \mathrm{ml}$ \\
9 & Enterrococci & $0 / 100 \mathrm{ml}$ \\
10 & Total bacterial count & $0 / 100 \mathrm{ml}$ \\
\hline
\end{tabular}

\section{DISCUSSION}

The quality of water is related to mortality and morbidity because water is life and without water nobody can survive. For survival, drinking water must not contain components which have hazardous and deleterious effects on human health, such as disease causing microorganisms, minerals and organic materials (Haydar et al., 2009). Most of the people in developing countries suffer from diseases related to either an inadequate supply of drinking water or bad quality of water (Leeuwen, 2000). Physico-chemical properties such as temperature, $\mathrm{pH}$, total dissolved solid, electrical conductivity, and dissolved oxygen indicate the quality of water or the ability of water to support the microbial growth. These characteristics are important parameters for screening water quality (APHA, 1998).

The population of Gilgit Baltistan is scattered in the form of villages. All places or villages have their own water resources like precipitation, stream flow, springs, etc. These water resources are used for drinking as well as irrigation purpose. In the current study, all the water samples collected from the Mishto uch and Bar springs of Sherqilla valley analyzed the physico-chemical and bacteriological properties of water. The quality of water used for drinking purposes revealed that some of the chemical and microbial parameters are exceeding those outlined by WHO standards. The physical parameters like temperature, conductivity, and total dissolved solid for all the collected water samples during winter and spring seasons were within the permissible limits set by WHO (1993).

During this investigation, there was slight variation in the temperature of sampling points of Mishto uch and Bar springs. The temperature of Mishto uch samples was in a range of $9.5^{\circ} \mathrm{C}-16^{\circ} \mathrm{C}$ while Bar has $10^{\circ} \mathrm{C}-17^{\circ} \mathrm{C}$, although it is important to note that Mishto uoch is at a high elevation compared to Bar. This slightly higher temperature may be due to degree of shade over the spring sites of Mishto uch (Ekhaise and Anyansi, 2005).

The electrical conductivity of all tested samples ranged from $143 \mu \mathrm{S} / \mathrm{cm}-287 \mu \mathrm{S} / \mathrm{cm}$. The WHO (1993) suggested limits of $1000 \mu \mathrm{S} / \mathrm{cm}$ for electrical conductivity was not exceeded by any of the collected water samples under study. Generally, geology of the area through which water flows affects the electrical conductivity of water (APHA, 1992). These results corroborate with the results of Akubuenyi et al. (2013) where conductivity was found in a range of $5.30-24.7 \mu \mathrm{S} / \mathrm{cm}$ in cross river state, Nigeria and Kirubavathy et al. (2005) in Erode District, Tamil Nadu during the assessment of quality of water of the Orthupalayam reservoir.

Values of water sample TDS parameters fall within the desirable limit of $500 \mathrm{mg} / \mathrm{l}$ (WHO, 1993). TDS were present in range of $31 \mathrm{mg} / 1-145 \mathrm{mg} / 1$ as it is the sum of concentration of cations and anions that shows the density of water and reduces the solubility of different gases in water (Soni et al., 2013).

In the terms of turbidity, all water samples showed very low values from $0.14 \mathrm{NTU}$ to $0.91 \mathrm{NTU}$. These values were within the standard of 00-5NTU prescribed by WHO.

The $\mathrm{pH}$ values of all the collected samples were within the range of $6.5-7.2$.

Chemical parameters like reactive orthophosphate 
were present in a range of $21 \mu \mathrm{gP} / \mathrm{L}-48 \mu \mathrm{gP} / \mathrm{L}$ at the sampling sites of Bar spring in both Winter and Spring. While in Mishto uch spring, it ranged from $19 \mu \mathrm{gP} / \mathrm{L}$ $63 \mu \mathrm{gP} / \mathrm{L}$. All the sampling points of Mishto uch and Bar spring tested for reactive orthophosphate were within the desirable limits of WHO, except the spring source of Mishto uch which showed a slightly elevated value in spring. Total phosphorus was present in a range of $39 \mu \mathrm{gP} / \mathrm{L}$ - $134 \mu \mathrm{gP} / \mathrm{L}$ at both springs in both winter and spring and were higher than permissible limits of WHO (1993).

According to WHO (1993) there should be no microorganisms in $100 \mathrm{ml}$ of drinking water. In the springs, the total bacterial counts were observed even in the eye of the spring. As according to the standard guidelines of WHO, 0 CFU $/ 100 \mathrm{ml}$ of TBC is suitable for drinking. This result is in agreement with the study of Odeyemi et al. (2011) who conducted a study on the water samples of an artesian bore-hole, spring and hand dug well located at Oke-Osun, Ikere-Ekiti, Nigeria and found TBC in a range of $76.9 \mathrm{CFU} / 100 \mathrm{ml}$. The eye of the Bar spring should be protected from any type of approach of humans and animals to provide safe drinking water to the community of Sherqillah.

\section{CONCLUSION}

In the current study, it is concluded that the quality of water of Mishto uch and Bar spring are potable as their physico-chemical characteristics are within the limits of WHO guidelines. The quality of water from a bacteriological point of view was not satisfactory as the total bacterial counts of $E$. coli and Enterrococci exceeded the WHO permissible limits, thereby affecting the human health.

\section{RECOMMENDATIONS}

It is recommended that precautions should be taken to provide safe supply of drinking water to the communities to protect the eyes of both the springs and their distribution systems. The community of users utilizing both springs' water should be provided with hygiene education so the community may play an active role in improving the cleanliness of their water storage containers.

\section{Statement of conflict of interest}

The authors declare no conflict of interest.

\section{REFERENCES}

Ahmed, S. and Joyia, M.F., 2003. Northern areas strategy for sustainable development. IUCN
Background Paper, Water Pakistan Northern Areas Program.

Akubuenyi, F.C., Uttah, E.C. and Enyi-IDOH, K.H., 2013. Microbiological and physicochemical assessment of major sources of water for domestic uses in Calabar Metropolis, Cross River State, Nigeria. Transit. J. Sci. Technol., 3: 1857-8047.

APHA, 1992. Standard methods for examination of water and waste water, $17^{\text {th }}$ edition. America Public Health Association, New York, pp. 1268-1270.

APHA, 1998. Standard methods for examination of water and waste water, $20^{\text {th }}$ edition. American Public Health Association, New York, pp. 81-85.

Azizullah, A., Khattak, M.N., Picher, P. and Hader, D.P., 2011. Water pollution in Pakistan and its impact on public health. A-Rev. Environ. Int., 37: 479-497. https://doi.org/10.1016/j.envint.2010.10.007

Dan'azumi, S. and Bichi, M.H., 2010. Industrial pollution and heavy metal profile of Challawa River in Kano, Nigeria. J. appl. Sci. Environ. Sanit., 5: 23-29.

Ekhaise, F.O. and Anyansi, C.C., 2005. Influence of brewery effluent discharge on the microbiological and physicochemical quality of Ikpoba River, Nigeria. Afr. J. Biotechnol., 4: 1062-1065.

FAO/WHO, 1997. Risk management and food safety: Report of a joint consultation in collaboration with World Health Organization. WHO, Rome, Italy, pp. 27-31.

FAO, 1997a. Chemical analysis manual for food and water, 5th Ed. Food And Agriculture Organization 1: $20-26$.

GoP, 2005. Medium term development framwork 2005/10. Planning and Development Division, Federal Bureau of Statistics, Government of Pakistan.

Holgate, G., 2000. Water quality: DETR consulation on new regulations for drinking water. Environ. Waste Manage., 3: 105-112.

GBPI, 2009. Gilgit-Baltistan empowerment and selfgovernance order. Gilgit-Baltistan Policy Institute, Centre For Civic Education, Pakistan.

Haydar, S., Arshad, M. and Aziz, J.A., 2009. Evaluation of drinking water quality in urban areas of Pakistan: A case study of Southern Lahore. Pak. J. Engin. appl. Sci., 5: 16-23.

Jackson, R.B., Carpenter, S.R., Dahm, C.N., McKnight, D.M., Naiman, R.J., Postel, S.L. and Running, S.W., 2001. Water in a changing world. Ecol. Appl., 11: 1027-1045. https://doi.org/10.1890/10510761(2001)011[1027:WIACW]2.0.CO;2

Khan, A.A., 2000. Fluoride levels in drinking water of 
Pakistan. Pak. J. med. Res., 39: 52-60.

Khan, F. J. and Javed, Y., 2007. Delivering access to safe drinking water and adequate sanitation in Pakistan. Pakistan Institute of Development Economics.

Kirubavathy, A.K., Binukumari, S., Mariamma, N. and Rajammal, T., 2005. Assessment of water quality of Orthupalayam reservoir, Erode District, Tamil Nadu. J. Ecophysiol. Occupat. Hlth., 5: 53-54.

Kahlown, M.A., Tahir, M.A., Rasheed, H. and Bhatti, K.P., 2006. Water quality status, Fourth Technical Report. National Water Quality Monitoring Programme, Pakistan Council of Research in Water Resources.

Lloyd, B. and Helmer, R., 1992. Surveillance of drinking water quality in rural area. Longman Scientific and Technical Publication, New York, pp. 34-56.

Leeuwen, F.X.R., 2000. Safe drinking water: the toxicologist's approach. Fd. Chem. Toxicol., 38(Suppl. 1): 51-58. https://doi.org/10.1016/ S0278-6915(99)00140-4

Montgomery, M.A. and Elimelech, M., 2007. Water and sanitation in developing countries: Including health in the equation. Environ. Sci. Technol., 41: 17-24. https://doi.org/10.1021/es072435t

Munair, S., 2003. Protection of water resources in Northern Punjab. Water-A vital source of life, international year of freshwater. The United Nations System in Pakistan.

Malcolm-Lawes, D.J. and Wong, K.H., 1990. Determination of orthophosphate in water and soil using a flow analyzer. Analyst, 15: 65-67. https:// doi.org/10.1039/an9901500065

Odeyemi, A.T., Akinjogunla, O.J. and Ojo, M.A., 2011. Bacteriological, physicochemical and mineral studies of water samples from Artesian bore-hole, spring and hand dug well located at Oke-Osun, Ikere-Ekiti, Nigeria. Arch. appl. Sci. Res., 3: 94108.

Pote, D.H. and Daniel, T.C., 2001. Analyzing for dissolved reactive P in water samples. South. Coop. Ser., 396: 91-93.

PCO, 2008. Country paper on 2008 population and housing census of Pakistan. Presented in management seminar for heads of National Statistical Offices in Asia and The Pacific, Daejeon, Republic of Korea, $18-20^{\text {th }}$ September, 2006. Population Census Organization, Statistics
Division, Government of Pakistan.

Rowland, A.P. and Haygarth, P.P., 1997. Determination of total dissolved phosphorus in soil solutions. $J$. environ. Qual., 2: 410-415. https://doi.org/10.2134/ jeq1997.00472425002600020011x

Rajkumar, N.S., Nongbri B. and Patwardhan A.M., 2003. Physico-chemical and microbial analysis of Umiam (Barapani) lake water. India J. environ. Prot., 23: 633-639.

Simpi, B., Hiremath, S.M. and Murthy, K.N.S., 2011. Analysis of water quality using physico-chemical parameters hosahalli tank in Shimoga District, Karnataka, India. Glob. J. Sci. Front. Res., 11: 1-5.

Soni, V.K., Visavadia, M., Gosai, C., Hussain, M.D., Mewada, M.S., Gor, S. and Salahuddin, K., 2013. Evaluation of physico-chemical and microbial parameters on water quality of Narmada River, India. Afr. J. environ. Sci. Technol., 7: 469-503.

Tamot, P. and Bhatnagar, G.P., 1988. Limnological studies of upper lake Bhopal. In: Proceedings of national symposium: Past present and future of Bhopal lakes (ed. S.K. Kulshreshtha), pp. 37-40.

The United Nations System in Pakistan, 2003. Water-A vital source of life. Islamabad, pp. 63.

Thompson, P. and Khan, A., 2003 Phytoplankton responses to wastewater discharges at two sites in Western Australia. Mar. Freshw. Res., 54: 721-735. https://doi.org/10.1071/MF02096

UNDP, 2006. Beyond scarcity: Power, poverty and the global water crisis. Human Development Report 2006, United Nations Development Programs, New York.

WHO, 1993. Guidelines for drinking water supply. World Health Organization, Geneva, Switzerland.

WHO, 2003. Emerging issues in water and infectious disease. World Health Organization, Geneva, Switzerland.

WHO, 2004. DDT and its derivatives in drinking-water. World Health Organization, Geneva, Switzerland.

World Bank, 2002a. Report of second structural adjustment credit program. International Development Association Program and Government of North-West Province, Pakistan.

World Bank, 2002b. Water, sanitation and hygiene at a glance: Health, Nutrition and Population Sector Act Sheet. The World Bank, Washington, DC. 